The Amide Group as Modulator of Crystalline and Liquid Crystalline Structures in Isocyano-alkylanilide Silver(I) Complexes.

María J. Baena, Silverio Coco, Pablo Espinet.*

IU CINQUIMA/Química Inorgánica, Facultad de Ciencias, Universidad de Valladolid, 47071Valladolid, Spain

Silver(I) complexes $\left[\mathrm{AgX}(\mathrm{CNR}]\right.$ and $\left[\mathrm{Ag}(\mathrm{CNR})_{2}\right] \mathrm{X}(\mathrm{X}=$ anionic ligand $)$, containing an amidefunctionalized isocyanide, $\mathrm{CNR}=\mathrm{CN}-\mathrm{C}_{6} \mathrm{H}_{4}-\mathrm{NHCOR}$, have been synthesized and their X-ray structures have been determined for $\left[\mathrm{Ag}(\mathrm{X})\left(\mathrm{CN}-\mathrm{C}_{6} \mathrm{H}_{4}-\mathrm{NHCOCH}_{3}\right)\right]\left(\mathrm{X}=\mathrm{NO}_{3}{ }^{-}, \mathrm{CF}_{3} \mathrm{SO}_{3}{ }^{-}\right)$and $\left[\mathrm{Ag}\left(\mathrm{CN}-\mathrm{C}_{6} \mathrm{H}_{4}-\mathrm{NHCOCH}_{3}\right)_{2}\right] \mathrm{X}\left(\mathrm{X}=\mathrm{NO}_{3}{ }^{-}, \mathrm{CF}_{3} \mathrm{SO}_{3}{ }^{-}, \mathrm{BF}_{4}{ }^{-}\right)$. All the crystal structures show a packing of polymeric chains formed through $\mathrm{Ag}-\mathrm{O}=\mathrm{C}_{\text {amide }}$ interactions. These chains associate in layers through hydrogen bonds involving the amide group, and by further interactions of the metal ion with oxygen-donor moieties. Substitution of the Me group in the amide by a nonyl chain $\left(\mathrm{R}=\mathrm{C}_{9} \mathrm{H}_{19}\right)$ leads to neutral $\left[\mathrm{Ag}\left(\mathrm{NO}_{3}\right)\left(\mathrm{CN}-\mathrm{C}_{6} \mathrm{H}_{4}-\mathrm{NHCOC}_{9} \mathrm{H}_{19}\right)\right]$ and ionic $\left[\mathrm{Ag}\left(\mathrm{CN}-\mathrm{C}_{6} \mathrm{H}_{4}-\right.\right.$ $\left.\left.\mathrm{NHCOC}_{9} \mathrm{H}_{19}\right)_{2}\right] \mathrm{X}\left(\mathrm{X}=\mathrm{NO}_{3}{ }^{-}, \mathrm{CF}_{3} \mathrm{SO}_{3}{ }^{-}, \mathrm{H}_{25} \mathrm{C}_{12} \mathrm{OSO}_{3}{ }^{-}, \mathrm{BF}_{4}{ }^{-}\right)$mesomorphic complexes. All of them display smectic liquid crystalline phases compatible with the crystal structures found for the methyl derivatives, and FTIR/ATR spectroscopy confirms that the intermolecular interactions observed in the solid state are preserved in the mesophase.

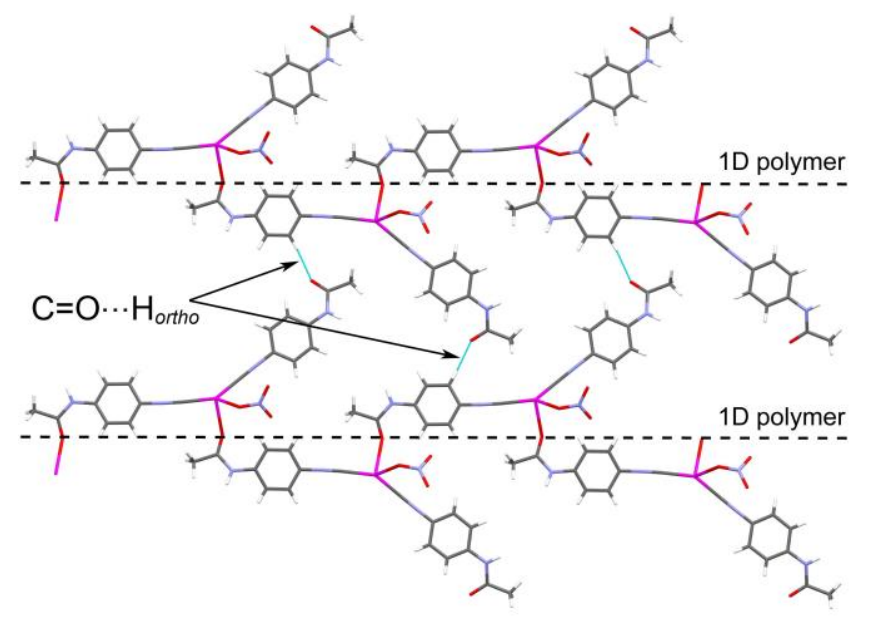

*Corresponding author : e-mail: espinet@qi.uva.es ; Tel.: +34 983186336 


\title{
The Amide Group as Modulator of Crystalline and Liquid Crystalline Structures in Isocyano-alkylanilide Silver(I) Complexes.
}

\author{
María J. Baena, Silverio Coco, Pablo Espinet.* \\ IU CINQUIMA/Química Inorgánica, Facultad de Ciencias, Universidad de Valladolid, \\ 47071-Valladolid, Spain \\ *Corresponding author e-mail: espinet@qi.uva.es
}

\begin{abstract}
Silver(I) complexes $\left[\mathrm{AgX}(\mathrm{CNR}]\right.$ and $\left[\mathrm{Ag}(\mathrm{CNR})_{2}\right] \mathrm{X}(\mathrm{X}=$ anionic ligand $)$, containing an amidefunctionalized isocyanide, $\mathrm{CNR}=\mathrm{CN}-\mathrm{C}_{6} \mathrm{H}_{4}-\mathrm{NHCOR}$, have been synthesized and their $\mathrm{X}$-ray structures have been determined for $\left[\mathrm{Ag}(\mathrm{X})\left(\mathrm{CN}-\mathrm{C}_{6} \mathrm{H}_{4}-\mathrm{NHCOCH}_{3}\right)\right]\left(\mathrm{X}=\mathrm{NO}_{3}{ }^{-}, \mathrm{CF}_{3} \mathrm{SO}_{3}{ }^{-}\right)$and $\left[\mathrm{Ag}\left(\mathrm{CN}-\mathrm{C}_{6} \mathrm{H}_{4}-\mathrm{NHCOCH}_{3}\right)_{2}\right] \mathrm{X}\left(\mathrm{X}=\mathrm{NO}_{3}{ }^{-}, \mathrm{CF}_{3} \mathrm{SO}_{3}{ }^{-}, \mathrm{BF}_{4}{ }^{-}\right)$. All the crystal structures show a packing of polymeric chains formed through $\mathrm{Ag}-\mathrm{O}=\mathrm{C}_{\text {amide }}$ interactions. These chains associate in layers through hydrogen bonds involving the amide group, and by further interactions of the metal ion with oxygen-donor moieties. Substitution of the Me group in the amide by a nonyl chain $\left(\mathrm{R}=\mathrm{C}_{9} \mathrm{H}_{19}\right)$ leads to neutral $\left[\mathrm{Ag}\left(\mathrm{NO}_{3}\right)\left(\mathrm{CN}-\mathrm{C}_{6} \mathrm{H}_{4}-\mathrm{NHCOC}_{9} \mathrm{H}_{19}\right)\right]$ and ionic $\left[\mathrm{Ag}\left(\mathrm{CN}-\mathrm{C}_{6} \mathrm{H}_{4}\right.\right.$ $\left.\left.\mathrm{NHCOC}_{9} \mathrm{H}_{19}\right)_{2}\right] \mathrm{X}\left(\mathrm{X}=\mathrm{NO}_{3}{ }^{-}, \mathrm{CF}_{3} \mathrm{SO}_{3}{ }^{-}, \mathrm{H}_{25} \mathrm{C}_{12} \mathrm{OSO}_{3}{ }^{-}, \mathrm{BF}_{4}{ }^{-}\right)$mesomorphic complexes. All of them display smectic liquid crystalline phases compatible with the crystal structures found for the methyl derivatives, and FTIR/ATR spectroscopy confirms that the intermolecular interactions observed in the solid state are preserved in the mesophase.
\end{abstract}




\section{INTRODUCTION}

Isocyanides (CNR) are versatile ligands of high importance in organometallic chemistry, catalysis, materials science, or diagnostic medicine. ${ }^{1}$ Their chemical behavior depends on the electronic and structural features of the $\mathrm{R}$ group, which modulates their properties and consequently those of their metal complexes. Isocyanides containing a second functional group are especially interesting. A number of these bifunctional isocyanides and their metal complexes have been used in catalysis, ${ }^{2}$ supramolecular chemistry, ${ }^{3}$ and nanochemistry. ${ }^{4}$ 4Isocyanoacetanilide, $\mathrm{CN}_{-} \mathrm{C}_{6} \mathrm{H}_{4}-\mathrm{NHCOCH}_{3}$ is one of these functionalized isocyanides. Its synthesis was reported in $1997,{ }^{5}$ but its coordination chemistry was not explored.

Silver(I) is well known to exhibit different types of coordination geometries (linear, bent, trigonal planar, T-shaped, tetrahedral, trigonal pyramidal, etc.) in its complexes with multitopic ligands, generating a variety of $1 \mathrm{D}, 2 \mathrm{D}$, and $3 \mathrm{D}$ architectures. ${ }^{6,7}$ These systems have been widely investigated for the rational design of functional solids on the basis of controlling intermolecular interactions and coordination bonds, ${ }^{8,9}$ but not many examples are based on silver complexes with functionalized isocyanides. ${ }^{10,11}$ These include complexes $[\mathrm{AgX}(\mathrm{CNR})](\mathrm{X}=$ anionic ligand $)$ with a wide structural diversity ranging from monomeric to polymeric structures and involving different coordination geometries of the silver atom, ${ }^{10 b, 11,12,13}$ and also a few cationic bisisocyanide complexes $\left[\mathrm{Ag}(\mathrm{CNR})_{2}\right] \mathrm{X} .^{10}$

We therefore decided to study the coordination ability of 4-isocyanoacetanilide towards $\operatorname{Ag}(\mathrm{I})$, and explore the possibility of modifying the formation of different supramolecular structures by modulating the intermolecular interactions, which can be achieved through the amide group. These interactions include the formation of direct intermolecular hydrogen bonds not only between amide groups of different molecules, ${ }^{14}$ but also with water molecules or anionic ligands 
present in the system. Moreover, the possibility that some interactions could be established between the metal atom and the amide carbonyl group should not be excluded. The features of the alkyl substituent of the amide can also play an important role to tune the properties of the complex. In this sense, it is hoped that the presence of a long alkyl chain on the amide group might lead to liquid crystalline materials. Although there are many reports on argentomesogens in the literature, ${ }^{15}$ mesomorphic complexes based on isocyanide silver derivatives are scarce. ${ }^{16,17}$

Here we report 4-isocyanoacetanilide silver complexes $[\mathrm{AgX}(\mathrm{CNR})]\left(\mathrm{X}=\mathrm{NO}_{3}{ }^{-}(2), \mathrm{CF}_{3} \mathrm{SO}_{3}{ }^{-}\right.$ (3)) and $\left[\mathrm{Ag}(\mathrm{CNR})_{2}\right] \mathrm{X}\left(\mathrm{X}=\mathrm{NO}_{3}^{-}(4), \mathrm{CF}_{3} \mathrm{SO}_{3}^{-}(5), \mathrm{BF}_{4}^{-}(6)\right)$. Their X-ray diffraction structures show in all cases the formation of layered supramolecular structures supported by hydrogen bonding, and $\mathrm{Ag}-\mathrm{O}$ interactions involving mainly the amide group and the anionic ligand present in the complexes. The same kind of complexes, but bearing a long alkyl chain as substituent on the amide group $(\mathrm{CNR}=4$-isocyanodecylanilide), display liquid crystalline behavior. The smectic mesophase generated is compatible with the solid-state supramolecular packing found in the methyl complexes.

\section{EXPERIMENTAL SECTION}

Materials and general methods. Commercial reagents and solvents were used as provided, unless specified, and the reactions were carried out under inert atmosphere. Elemental analyses were performed on a Perkin-Elmer 2400 microanalyzer. IR spectra were recorded in a Perkin Elmer Frontier spectrometer coupled to a Pike GladiATR-210 accessory. The spectra recorded at variable temperature were collected each $10{ }^{\circ} \mathrm{C}$ to a rate of $10{ }^{\circ} \mathrm{C} / \mathrm{min}$ in the same apparatus. ${ }^{1} \mathrm{H}$ and ${ }^{13} \mathrm{C}-\mathrm{NMR}$ spectra were recorded in Bruker AV-400 or Varian-500 MHz spectrometers, in deuterated acetone. Transition temperatures and enthalpies were measured by differential 
scanning calorimetry, with a Perkin-Elmer DSC-7, using aluminum crucibles and at a rate of 10 ${ }^{\circ} \mathrm{C} / \mathrm{min}$. The apparatus was calibrated with indium $\left(156.6^{\circ} \mathrm{C}, 28.45 \mathrm{Jg}^{-1}\right)$ as standard. The textures of the mesophases were studied with a Leica polarizing microscope mod. DMRB, equipped with a Mettler FP-82HT hot stage and a temperature controller Mettler FP-90.

Synthesis. Details on the synthesis and characterization of the isocyanides and its complexes are given in the Supplementary Information.

X-Ray Crystallography. Crystal evaluation and data collection of 2, 3, 5 and 6 were performed on an Oxford Diffraction Supernova diffractometer, equipped with an Atlas charge-coupled device $(\mathrm{CCD})$ area detector and a four-circle $\kappa$ goniometer. Suitable single crystals were mounted in glass fibers. Data collection was performed with a Mo microfocus source $(\lambda=$ $0.71073 \AA$ ) with multilayer optics. Data integration, scaling and empirical absorption correction was carried out using the CrysAlis Pro program package. ${ }^{18}$ Single-crystal X-ray diffraction data for 4 were collected on a Bruker SMART CCD using Mo Ka radiation, as previously described. ${ }^{19}$ The structures were solved by direct methods and refined anisotropically on $F^{2}{ }^{20}$ All non-hydrogen atomic positions were located in difference Fourier maps and refined anisotropically. The structure was solved by direct methods and refined anisotropically on $F^{2}{ }^{21}$ All non-hydrogen atomic positions were located in difference Fourier maps and refined anisotropically. The hydrogen atoms were placed in their geometrically generated positions. Compounds $\mathbf{2}$ and $\mathbf{6}$ were refined by the Flack method for the determination of the absolute structure. ${ }^{22}$ Both values of the Flack parameter are collected in Table 1. Details of crystal parameters, data collection, and structure refinements are given in Table 1. CCDC reference numbers for 2-6: CCDC 1011688-1011692. 
Table 1. Crystal data and structure refinements for complexes $2-6$

\begin{tabular}{llllll}
\hline & $\mathbf{2}$ & $\mathbf{3}$ & $\mathbf{4}$ & $\mathbf{5}$ & $\mathbf{6}$ \\
\hline Formula & $\mathrm{C}_{9} \mathrm{H}_{8} \mathrm{AgN}_{3} \mathrm{O}_{4}$ & $\mathrm{C}_{20} \mathrm{H}_{18} \mathrm{Ag}_{2} \mathrm{~F}_{6} \mathrm{~N}_{4} \mathrm{O}_{9} \mathrm{~S}_{2}$ & $\mathrm{C}_{18} \mathrm{H}_{16} \mathrm{Ag} \mathrm{N}_{5} \mathrm{O}_{5}$ & $\mathrm{C}_{19} \mathrm{H}_{16} \mathrm{AgF}_{3} \mathrm{~N}_{4} \mathrm{O}_{5} \mathrm{~S}$ & $\mathrm{C}_{18} \mathrm{H}_{16} \mathrm{AgBF}_{4} \mathrm{~N}_{4} \mathrm{O}_{2}$ \\
$\mathrm{Fw}$ & 330.05 & 852.24 & 490.23 & 577.28 & 515.03 \\
$\mathrm{~T}(\mathrm{~K})$ & $293(2)$ & $293(2)$ & $298(2)$ & $293(2)$ & $293(2)$ \\
$\lambda(\AA)$ & 0.71073 & 0.71073 & 0.71073 & 0.71073 & 0.71073 \\
Cryst syst & Orthorombic & Monoclinic & Monoclinic & Triclinic & Monoclinic \\
Space group & $\mathrm{P} 212121$ & $\mathrm{P} 21 / \mathrm{n}$ & $\mathrm{P} 21 / \mathrm{n}$ & $\mathrm{P}-1$ & $\mathrm{C} 1 \mathrm{c} 1$ \\
$a(\AA)$ & $5.4990(4)$ & $8.4116(4)$ & $10.9803(18)$ & $10.0223(7)$ & $11.6416(5)$ \\
$b(\AA)$ & $9.3162(9)$ & $11.5062(4)$ & $15.495(3)$ & $15.5062(11)$ & $15.9955(4)$ \\
$c(\AA)$ & $21.4233(13)$ & $29.4257(15)$ & $12.646(2)$ & $15.8636(11)$ & $12.1545(4)$ \\
$\alpha($ deg $)$ & 90 & 90 & 90 & $95.755(6)$ & 90 \\
$\beta\left({ }^{\circ}\right.$ deg & 90 & $94.295(4)$ & $112.908(4)$ & $102.232(6)$ & $113.130(5)$ \\
$\gamma($ deg $)$ & 90 & 90 & 90 & $104.701(6)$ & 90 \\
$\mathrm{~V}\left(\AA^{3}\right)$ & $1097.51(15)$ & $2840.0(2)$ & $1981.9(6)$ & $2299.3(3)$ & $2081.40(13)$ \\
$\mathrm{Z}$ & 4 & 4 & 4 & 4 & 4 \\
$\left.\mu(\mathrm{mm})^{-1}\right)$ & 1.843 & 1.620 & 1.057 & 1.029 & 1.025 \\
No. reflns & 2055 & 5760 & 2853 & 9510 & 4810 \\
No. param & 155 & 398 & 274 & 599 & 267 \\
$\mathrm{GOF}\left(\mathrm{F}^{2}\right)$ & 1.134 & 1.018 & 1.043 & 1.040 & 1.028 \\
$\mathrm{R}_{\text {int }}$ & 0.0242 & 0.0394 & 0.0499 & 0.0532 & 0.0366 \\
$\mathrm{R}_{1}(\mathrm{I}>2 \sigma)$ & 0.0403 & 0.0595 & 0.0386 & 0.0733 & 0.0441 \\
$w R_{2}(\mathrm{I}>2 \sigma)$ & 0.0777 & 0.1334 & 0.0824 & 0.1912 & 0.1131 \\
Flack param. & $0.08(7)$ & & & & $-0.03(4)$ \\
& & & & &
\end{tabular}

Powder X-ray diffraction. A Bruker D8 Discover A25 diffractometer operating with monochromatic $\mathrm{Cu}-\mathrm{K}_{\alpha 1}$ radiation $(1.5406 \AA)$ was used. Data were collected in Bragg-Bentano geometry using Si crystal as support and a linear Lynxeye detector. Theoretical PXRD patterns were generated from the crystallographic information files using the function provided by the Mercury software.

\section{RESULTS AND DISCUSSION}

\section{Synthesis and characterization}


The isocyanides 4-isocyanoacetanilide (1) and 4-isocyanodecylanilide (7) were prepared from the corresponding amine compounds by formylation to their $N$-formamides, followed by dehydration with bis(trichloromethyl)carbonate ("triphosgene") to the isocyanides CNR (Scheme 1). The isocyanides were isolated in good yield as pale yellow solids with not offending smell. 4Isocyanoacetanilide was reported some years ago by a slightly different method, with few characterization details. ${ }^{5} \mathrm{IR},{ }^{1} \mathrm{H}-$ and ${ }^{13} \mathrm{C}-\mathrm{NMR}$ spectroscopic data and $\mathrm{C}, \mathrm{H}, \mathrm{N}$ analysis are provided.

Scheme 1. Synthesis of the isocyanide ligands and their silver(I) complexes. i) HCOOH, toluene reflux. ii) $1 / 3\left(\mathrm{Cl}_{3} \mathrm{CO}\right)_{2} \mathrm{CO}, \mathrm{NEt}_{3}, \mathrm{CH}_{2} \mathrm{Cl}_{2}$

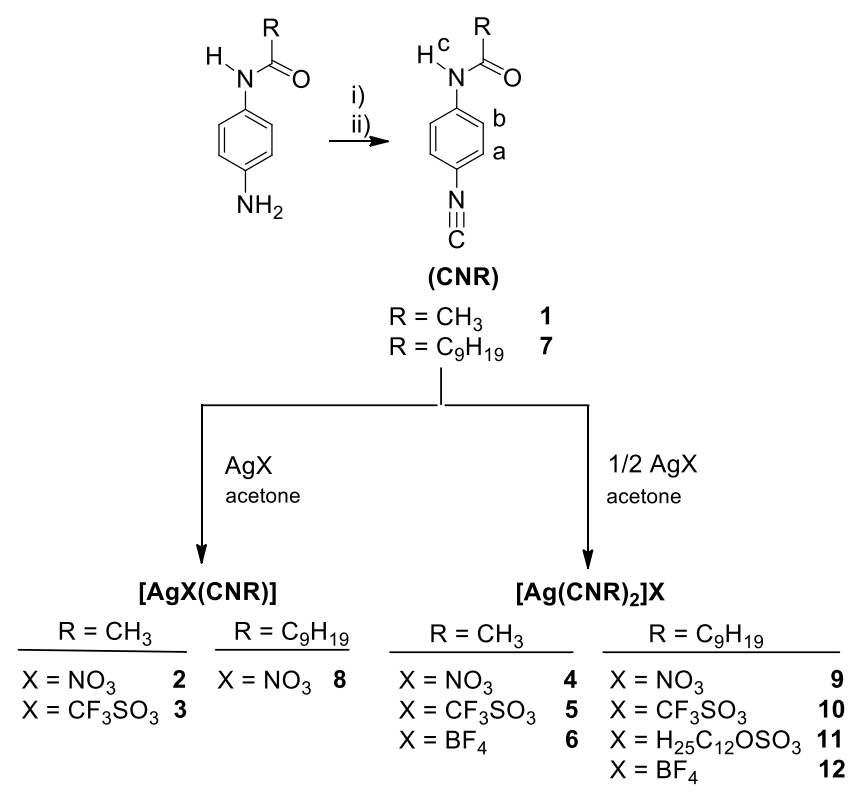

The IR spectra of $\mathbf{1}$ and $\mathbf{7}$ are similar and show a strong $v(\mathrm{C} \equiv \mathrm{N})$ absorption band at $c a .2120$ $\mathrm{cm}^{-1}$, strong $\mathrm{C}=\mathrm{O}$ and $\mathrm{N}-\mathrm{CO}$ stretching bands at $c a .1665$ and $1540 \mathrm{~cm}^{-1}$ respectively, and a broad $v(\mathrm{~N}-\mathrm{H})$ band at $c a .3300 \mathrm{~cm}^{-1}$. These data suggest the existence of intermolecular association through lateral $\mathrm{N}-\mathrm{H} \cdots \mathrm{O}=\mathrm{C}$ hydrogen bonding, as reported for acetanilide and for 
benzamides. ${ }^{23,24}$ In the ${ }^{1} \mathrm{H}$ NMR spectra of $\mathbf{1}$ and $\mathbf{7}$ in acetone- $\mathrm{d}_{6}$, the aryl hydrogen atoms appear at $400 \mathrm{MHz}$ as two distorted "doublets" (AA'BB' spin system) at 7.42 and $7.74 \mathrm{ppm}$. A broad singlet $(9.44 \mathrm{ppm})$ is observed for the N-H proton, and the alkyl hydrogen atoms appear in the range $0.8-2.1 \mathrm{ppm}$.

Silver complexes $\left[\mathrm{AgX}\left(\mathrm{CN}-\mathrm{C}_{6} \mathrm{H}_{4}-\mathrm{NHCOR}\right)\right] \quad\left(\mathrm{R}=\mathrm{CH}_{3}, \mathrm{X}=\mathrm{NO}_{3}^{-}(\mathbf{2}), \mathrm{CF}_{3} \mathrm{SO}_{3}^{-}(\mathbf{3}) ; \mathrm{R}=\right.$ $\left.\mathrm{C}_{9} \mathrm{H}_{19}, \mathrm{X}=\mathrm{NO}_{3}^{-}(\mathbf{8})\right)$ and $\left[\mathrm{Ag}(\mathrm{CNR})_{2}\right] \mathrm{X}\left(\mathrm{R}=\mathrm{CH}_{3}, \mathrm{X}=\mathrm{NO}_{3}{ }^{-}(4), \mathrm{CF}_{3} \mathrm{SO}_{3}{ }^{-}(\mathbf{5}), \mathrm{BF}_{4}{ }^{-}(\mathbf{6}) ; \mathrm{R}=\right.$ $\left.\mathrm{C}_{9} \mathrm{H}_{19}, \mathrm{X}=\mathrm{NO}_{3}^{-}(\mathbf{9}), \mathrm{CF}_{3} \mathrm{SO}_{3}^{-}(\mathbf{1 0}), \mathrm{H}_{25} \mathrm{C}_{12} \mathrm{OSO}_{3}^{-}(\mathbf{1 1}), \mathrm{BF}_{4}^{-}(\mathbf{1 2})\right)$ were prepared by reaction of 1 or 7 with the corresponding silver salts in 1:1 and 2:1 molar ratio, respectively (Scheme 1). $\mathrm{C}, \mathrm{H}, \mathrm{N}$ analysis, yields, and relevant IR and ${ }^{1} \mathrm{H}$ NMR data are given as Supporting Information. The silver complexes were isolated as air stable yellowish solids. The compounds are only moderately light sensitive and only after prolonged exposure to light (more than one day) they darken slightly. Reaction of $\mathrm{Ag}\left(\mathrm{BF}_{4}\right)$ with these isocyanides in 1:1 molar ratio failed to give $\left[\mathrm{Ag}\left(\mathrm{BF}_{4}\right)(\mathrm{CNR})\right]$, due to the weakness of $\mathrm{BF}_{4}{ }^{-}$as ligand, affording instead the cationic bisisocyanide complexes 6 and 12. For the same reason, $\left[\mathrm{Ag}\left(\mathrm{CF}_{3} \mathrm{SO}_{3}\right)\left(\mathrm{CN}-\mathrm{C}_{6} \mathrm{H}_{4}-\mathrm{NHCOC}_{9} \mathrm{H}_{19}\right)\right]$, could not be isolated pure and a mixture of the mono- and bis-isocyanide complexes was obtained.

The IR spectra of the solid silver complexes (2-6 and 8-12) show, as expected, $v(\mathrm{C} \equiv \mathrm{N})$ absorptions for the isocyanide group at higher wavenumbers $\left(\mathrm{ca} .65 \mathrm{~cm}^{-1}\right)$ than for the corresponding free isocyanides. ${ }^{17}$ In addition, their $v(\mathrm{~N}-\mathrm{H}), v(\mathrm{C}=\mathrm{O})$ and $v(\mathrm{~N}-\mathrm{CO})$ bands appear in the same region as for the free isocyanides, suggesting similar intermolecular interactions in the complexes and in the uncoordinated isocyanides. ${ }^{25}$ Furthermore, the bis-isocyanide complexes display two $v(\mathrm{C}=\mathrm{O})$ bands at $c a .1700$ and $1675 \mathrm{~cm}^{-1}$, indicating two types of amido groups involved in different intermolecular interactions, as confirmed by X-ray diffraction 
studies (see below). In acetonitrile solution, the IR spectra are similar, but the $v(\mathrm{C}=\mathrm{O})$ absorption appears in all cases as one intense band, at higher wavenumbers than in the solid state, revealing that the intermolecular interactions observed in the solid are not maintained in solution.

The ${ }^{1} \mathrm{H}-\mathrm{NMR}$ spectra of the silver complexes were recorded in acetone-d6, due to the low solubility of 2-6 in $\mathrm{CDCl}_{3}$, which suggests that the intermolecular interactions are broken in acetone solution. The spectra are quite similar to those of the free isocyanides, with small chemical shift differences as a result of coordination.

\section{X-ray diffraction structures.}

Compounds 2-6 have been characterized by single crystal and powder X-ray diffraction studies. The crystal data and experimental details are given in the Experimental Section in Table 1. Bond lengths and angles are listed in Tables S1-S5 in the Supporting Information. The ORTEP plots and unit cells are also included, as well as the experimental and calculated PXRD diffractograms. These last graphs are included to show that the structures calculated by single crystal DRX are representative of the bulk. Only the triflate complexes deviate to some extent from the theoretical patterns. We attribute the deviations in $\mathbf{3}$ to the loss of the water molecule in the microcrystalline sample (as supported by C, H, N analysis). For 5, the presence of more than one polymorph is suggested.

There is a common feature for all the crystalline structures of complexes 2-6: they are directed by $\mathrm{Ag}-\mathrm{O}=\mathrm{C}_{\text {amide }}$ coordination between neighboring molecules so that linear polymers are formed (Figure 1). These polymers assemble through hydrogen bonding to make a layer and the layers pack together in such a way that the $\operatorname{Ag}(\mathrm{I})$ achieves pseudo-tetrahedral coordination and is 
surrounded by the highest number of oxygen atoms. The molecules are achiral but in two cases ( 2 and 6) the structures are non centrosymmetric, probably due to that the molecular packing is governed by the electronic requirements of the metal center. Details are discussed below.

(a)
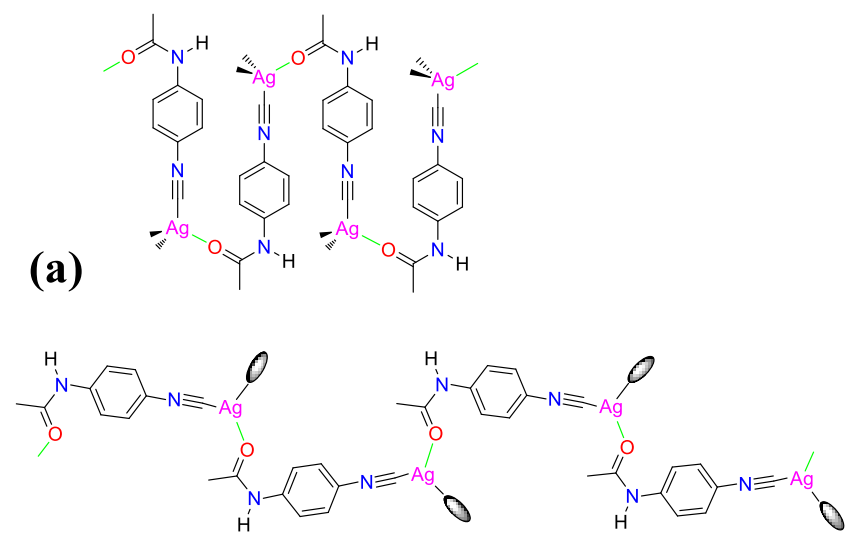

(b)

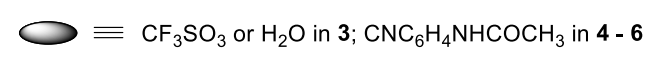

Figure 1. Linear polymers formed by $\mathrm{Ag}-\mathrm{O}=\mathrm{C}_{\text {amide }}$ coordination between neighboring molecules (green bond). (a) Antiparallel head-to-tail conformation in complex 2. (b) Parallel head-to tail conformation in complexes $3-\mathbf{6}$.

Mono-isocyanide complexes 2 and 3. $\left[\mathrm{Ag}\left(\mathrm{NO}_{3}\right)\left(\mathrm{CNC}_{6} \mathrm{H}_{4} \mathrm{NHCOCH}_{3}\right)\right]$ (2). Compound 2 crystallizes in the orthorhombic space group P2(1)2(1)2(1), with 4 formula units per unit cell. The individual molecule (Figure 2a) consists of a silver atom coordinated both to the carbon of an isocyanide group $(\mathrm{Ag}-\mathrm{C} 2.061(7) \AA)$ and to one oxygen atom of the nitrate group ( $\mathrm{Ag}-\mathrm{O}$ 2.304(5) $\AA$ ), all distances falling within normal ranges. ${ }^{12,13}$ The $\mathrm{O}_{2} \mathrm{NO}-\mathrm{Ag}-\mathrm{CNR}$ angle is quite far from linearity $\left(150.2(3)^{\circ}\right)$, due to the existence of two additional intermolecular interactions between the silver atom and the oxygen atoms of an amide group and a nitrate moiety of neighboring molecules, as discussed below.

The crystal packing of the complex shows association of molecules through an intermolecular $\mathrm{Ag} \cdots \mathrm{ONO}_{2}$ interaction $(\mathrm{Ag} \cdots \mathrm{O} 2.552(4) \AA)$ between crossed $-\mathrm{NC}-\mathrm{Au}-\mathrm{ONO}_{2}$ moieties in a head 
to head disposition (dihedral angle $-\mathrm{NC}-\mathrm{Ag} / \mathrm{Ag}{ }^{\prime}-\mathrm{C}^{\prime} \mathrm{N}^{\prime}-$ close to $90^{\circ}$ ), to give a molecular arrangement in layers. The staggered association of this type of layers via $\mathrm{Ag} \cdots \mathrm{O}$ (amide) interactions $(2.558(7) \AA$, in good agreement with standard values for bonding $\mathrm{Ag} \cdots \mathrm{O}$ contacts), ${ }^{26,12 \mathrm{f}}$ and $\mathrm{NH}^{\cdots} \cdot \mathrm{ONO}_{2}$ hydrogen bonding, produces the crystal packing with zigzag sequences shown in Figure 2b. None of the NH hydrogen atoms was located in a difference Fourier map, so their positions were calculated with a riding model. The $\mathrm{N}($ amide $) \cdots \mathrm{O}$ distance is $2.917(8) \AA$. After correction for a plausible N-H bond length based on neutron diffraction results, ${ }^{27}$ the estimated $\mathrm{H} \cdots \mathrm{O}$ distance is $1.917(8) \AA$ and the $\mathrm{N}-\mathrm{H} \cdots \mathrm{O}$ angle $162.8(4)^{\circ}$. The same corrections are applied for all hydrogen bonds discussed in this paper.

(a)
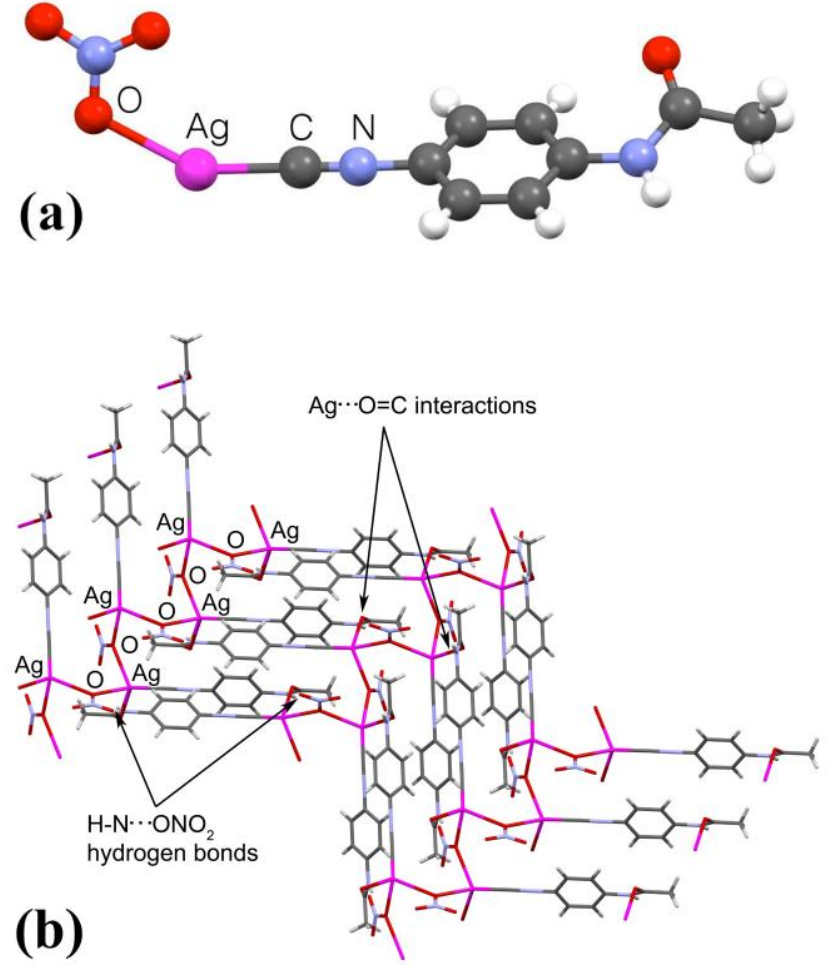

Figure 2. (a) Asymmetric unit for 2. (b) Crystal packing with zigzag sequences produced by the staggered association of perpendicular layers via $\mathrm{Ag} \cdots \mathrm{O}$ (amide) interactions and $\mathrm{NH}^{\cdots} \cdot \mathrm{ONO}_{2}$ hydrogen bonding. The perpendicular layers associate through $\mathrm{Ag} \cdots \mathrm{ONO}_{2}$ interactions. 
Therefore, two nitrate anions are coordinated to the metal center. Although in both cases $\mathrm{Ag}-\mathrm{O}$ distances fall within short $\mathrm{Ag} \cdots \mathrm{O}$ contact distances found in nitrate silver salts, ${ }^{28}$ one of them $(\mathrm{Ag}-\mathrm{O}=2.304(5) \AA)$ is shorter than the other $(\mathrm{Ag}-\mathrm{O}=2.552(4) \AA)$, revealing more covalent character in the first case. ${ }^{29}$ The acetanilide moiety displays a trans conformation, favored by the interaction between the $\mathrm{O}$-atom of the acetanilide and the ortho- $\mathrm{H}$ of the ring $\left(\mathrm{O} \cdots \mathrm{H}_{\text {aryl }}=\right.$ 2.362(5) $\AA$ ), as usually found in acetanilides. ${ }^{30}$ Remarkably, in complex 2 the dihedral angle between the $\mathrm{C}=\mathrm{O}$ and the ring $\left(31^{\circ}\right)$ is the highest for all the complexes $\mathbf{2}-\mathbf{6}$, forced by the headto-tail molecular arrangement in the perpendicular layers.

Complex 3 crystallizes in a monoclinic cell (space group P 21/n). Its asymmetric unit consists of two independent species (see Figure 3a), one neutral, $\left[\mathrm{Ag}\left(\mathrm{CF}_{3} \mathrm{SO}_{3}\right)(\mathrm{CNR})\right]$, and the other ionic, $\left[\mathrm{Ag}\left(\mathrm{H}_{2} \mathrm{O}\right)(\mathrm{CNR})\right] \mathrm{CF}_{3} \mathrm{SO}_{3}$. In the latter, a water molecule from the wet solvent has displaced the coordinated triflate group. This structure is less stable than $\mathbf{2}$, as the crystals become opaque over time, probably due to the loss of the water molecule.

Both molecules build their own linear coordination polymer through intermolecular $\mathrm{Ag} \cdots \mathrm{O}=\mathrm{C}$ interactions (Figure 3b). In turn, each kind of chain is connected to the other through weak interactions to build a layer $\left(\mathrm{N}-\mathrm{H} \cdots \mathrm{O}=1.865(8) \AA\left(172.8(4)^{\circ}\right)\right.$ and $1.872(7) \AA\left(164.8(4)^{\mathrm{o}}\right)$, $\mathrm{O} \cdots \mathrm{H}-\mathrm{O}=1.755(8) \AA\left(169.6(6)^{\circ}\right)$ and $1.805(8) \AA\left(166.0(9)^{\circ}\right)$. These layers are packed parallel, generating a layered structure driven by $\mathrm{Ag} \cdots \mathrm{O}$ interactions $\left(\mathbf{A g} \cdots \mathbf{O S O}_{2} \mathrm{CF}_{3}=2.874(5) \AA\right.$ and $\left.\mathbf{A g}{ }^{\cdots} \cdot \mathbf{O H}_{2}=2.879(6) \AA\right) .{ }^{27}$ All the triflate anions, whether coordinated or not, lie in the same interlayer space (Figure 3c). 

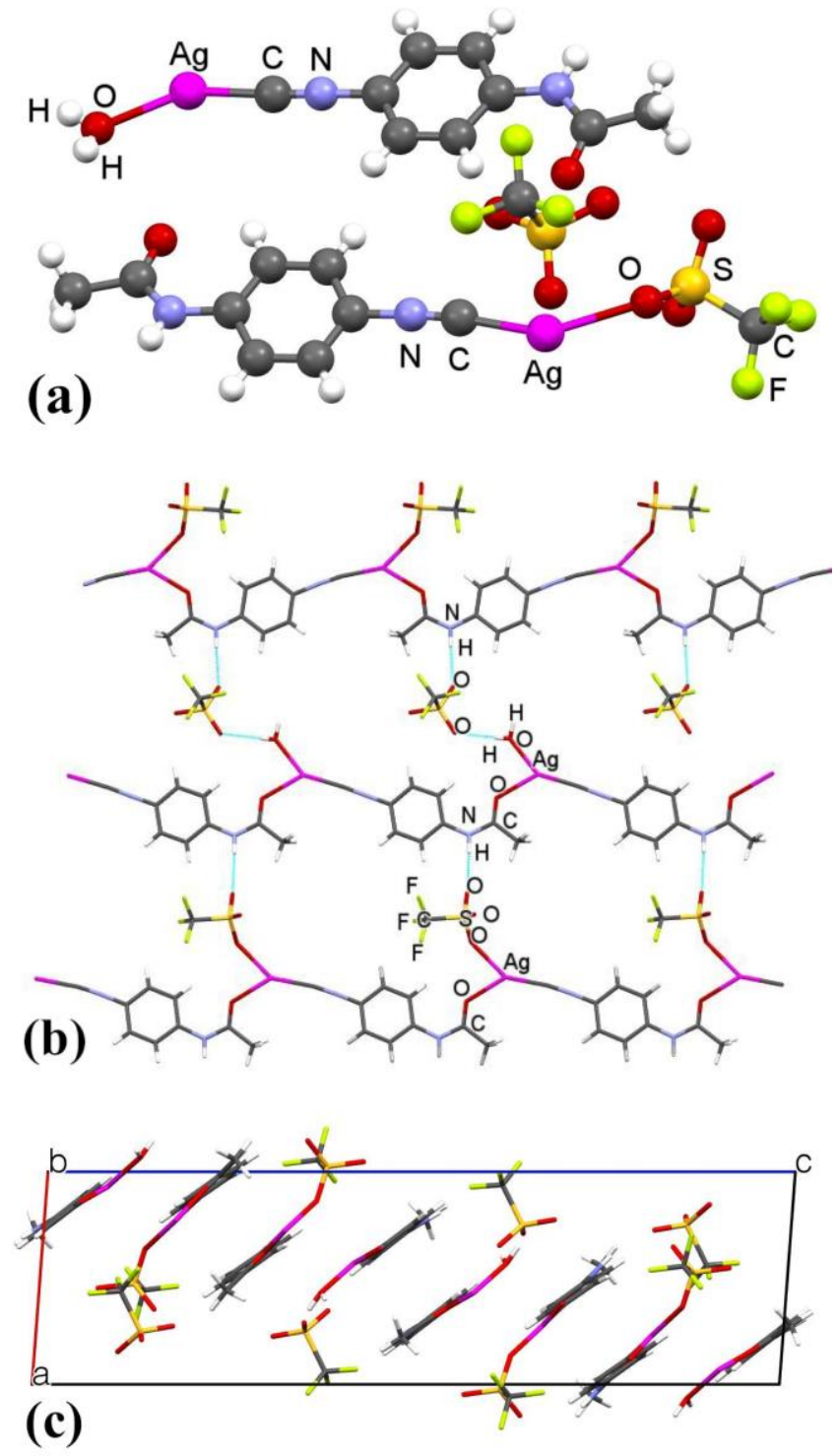

Figure 3. (a) Compound 3 asymmetric unit. (b) View of three 1D polymeric chains formed by the expansion of the two molecules of complex 3 . The association of these chains through weak interactions configures a layer. The interaction $\mathrm{O}-\mathrm{H} \cdots \mathrm{O}=1.775(8) \AA$ is not displayed for clarity in the drawing. (c) Monoclinic unit cell viewed down the $b$ axis.

Bis-isocyanide complexes 4-6. $\left[\mathrm{Ag}\left(\mathrm{CNC}_{6} \mathrm{H}_{4} \mathrm{NHCOCH}_{3}\right)_{2}\right] \mathrm{X}\left(\mathrm{X}=\mathrm{NO}_{3}^{-}{ }^{-}\right.$(4), $\mathrm{CF}_{3} \mathrm{SO}_{3}^{-}$(5) and $\mathrm{BF}_{4}^{-}$(6)]. Compounds 4, 5, and 6 crystallize in the monoclinic P21/n, triclinic P-1, and monoclinic Cc space groups, respectively, and their structures have many features in common 
(see Supporting Information for structural details). The cation $\left[\operatorname{Ag}(\mathrm{CNR})_{2}\right]^{+}$has a bent shape $(\mathrm{C}-$ Ag-C $=151-145^{\circ}$ ) and the amide groups of both isocyanides are placed in an anticonformation. These cations $\left[\mathrm{Ag}(\mathrm{CNR})_{2}\right]^{+}$are associated through intermolecular $\mathrm{Ag} \cdots \mathrm{O}=\mathrm{C}$ interactions ( $\mathrm{Ag} \cdots \mathrm{O}$ distances: 2.446(4) $\AA$ in 4, 2.385(5) and 2.440(6) $\AA$ in 5 and 2.444(4) $\AA$ in 6) giving a corrugate polymeric chain (Figure 4a). Each chain is disposed parallel to another (Figure 4b), generating a layer through intermolecular $\mathrm{C}=\mathrm{O} \cdots \mathrm{H}_{\text {ortho }}$ interactions. Taking compound 4 as a representative example, the estimated $\mathrm{O} \cdots \mathrm{H}$ distance is $2.224(9) \AA$, and the $\mathrm{C}$ $\mathrm{H} \cdots \mathrm{O}$ angle is $159.9(4)^{\circ} \cdot{ }^{27}$ Thus, both $\mathrm{C}=\mathrm{O}$ amide moieties of the bis-isocyanoacetanilide silver(I) complexes have different functions: one of them makes a link to a silver ion to build a 1D polymer; the other links the polymeric chains through weak hydrogen bonding, as suggested by the IR spectra discussed before.

Each layer is located parallel to another, generating a layered crystal packing (Figure $4 \mathrm{c}$ is a representative example). In $\mathbf{4}$ and $\mathbf{5}$ the layers are associated by pairs in such a way that the anion links one layer by $\mathrm{O} \cdots \mathrm{H}-\mathrm{N}$ hydrogen bonding and the other by $\mathrm{O}-\mathrm{Ag}$ interactions $\left(\mathrm{O}_{2} \mathrm{NO} \cdots \mathrm{H}-\mathrm{N}\right.$, $\mathrm{O} \cdots \mathrm{H}=1.893(8) \AA,\left(175.6(4)^{\circ}\right), 1.921(5) \AA\left(172.0(8)^{\circ}\right), \mathrm{Ag}-\mathrm{ONO}_{2}=2.648(5) \AA$ for 4 , $\mathrm{CF}_{3} \mathrm{O}_{2} \mathrm{SO} \cdots \mathrm{H}-\mathrm{N}, \quad \mathrm{O} \cdots \mathrm{H}: 1.797(1) \AA\left(171.2(5)^{\circ}\right), 1.893(1) \AA\left(170.5(5)^{\circ}\right)$ and $1.888(1) \AA$ $\left(169.9(5)^{\circ}\right), \mathrm{Ag}^{\cdots} \mathrm{OSO}_{2} \mathrm{CF}_{3}=2.943(6)$ for 5). In complex $\mathbf{6}$, the $\mathrm{BF}_{4}{ }^{-}$anion links to the layers through hydrogen bonds $\left(\mathrm{N}-\mathrm{H} \cdots \mathrm{F}=2.039(7) \AA,\left(164.8(4)^{\circ}\right)\right.$ and $\left.2.484(1) \AA\left(162.6(4)^{\circ}\right)\right)$ as a result of its non-coordinative nature. The $\operatorname{Ag}(\mathrm{I})$ position occupied in $\mathbf{4}$ and $\mathbf{5}$ by the anions is saturated in 6 by a free $\mathrm{C}=\mathrm{O}$ moiety of an amide group $(\mathrm{Ag} \cdots \mathrm{O}=\mathrm{C}=2.725(4) \AA)$. 

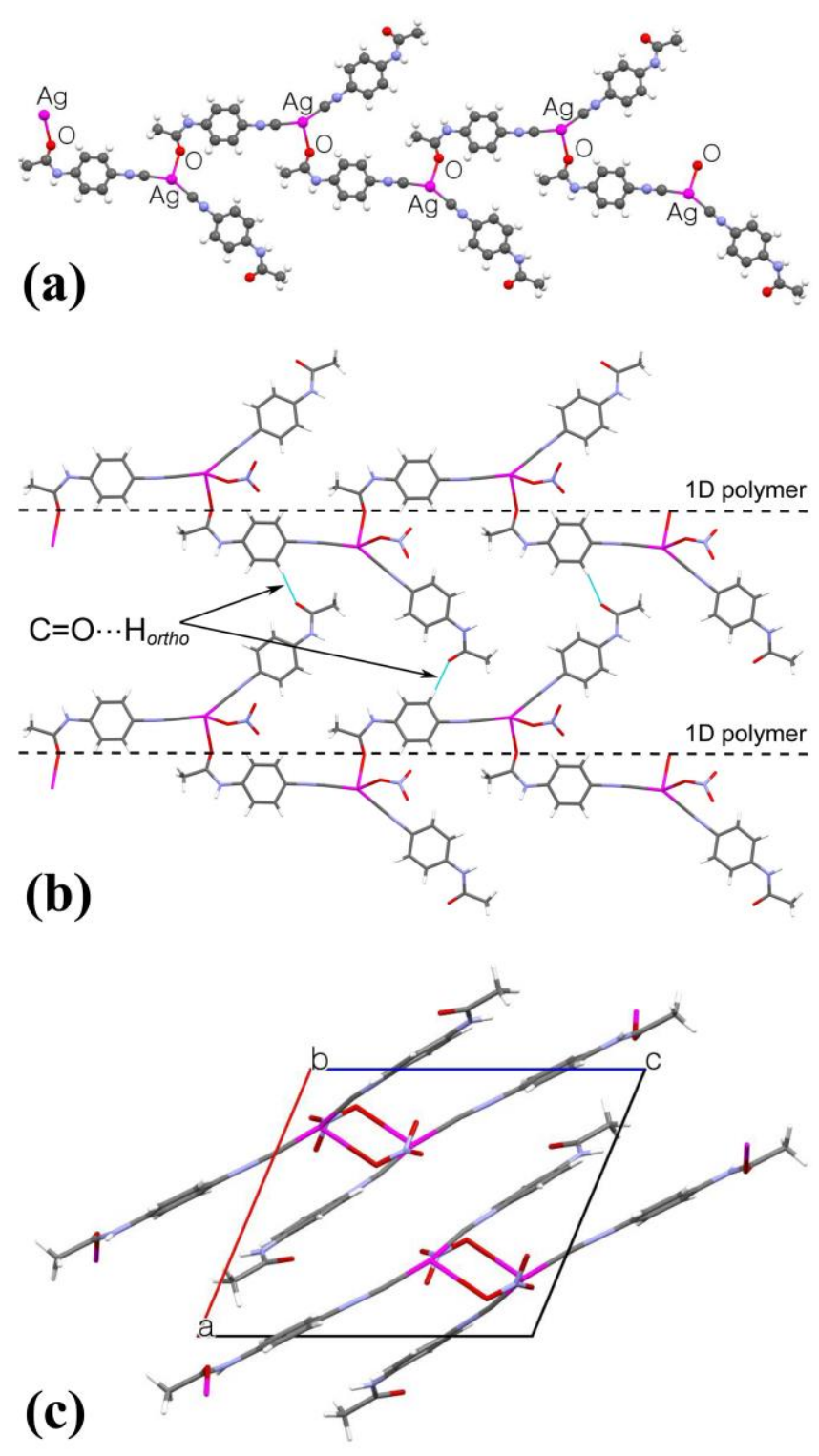

Figure 4. Molecular arrangement for 4. (a) Corrugate polimeric chain corresponding to the association of the cations. (b) View of the layer arrangement through intermolecular $\mathrm{C}=\mathrm{O} \cdots \mathrm{H}_{\text {ortho }}$ interactions. (c) Unit cell for $\mathbf{4}$ as a representative example of the layered structure of the bisisocyanide complexes.

The complexes reported here make a significant contribution to the so far scarce number of structurally described $\mathrm{Ag}(\mathrm{I})$-isocyanide complexes. ${ }^{10-13}$ At variance with structures previously reported, the use of a bifunctional isocyanide-amido ligand has allowed us to obtain polymeric layered structures. In addition, in contrast to other silver coordination polymers reported, ${ }^{31}$ in our case the structures obtained are governed by the several amido interactions with the metal and other groups and by the oxophilicity of $\operatorname{Ag}(\mathrm{I})$, while the influence of the anion is less important. 


\section{Mesomorphic behavior}

Compounds 1-6 melt with decomposition above $170{ }^{\circ} \mathrm{C}$. In contrast, although 4-isocyanodecylanilide $\mathbf{7}$ is not a liquid crystal itself, all its silver derivatives 8-12 display liquid crystal behavior. The anionic ligands are the same small groups as in $\mathbf{2}-\mathbf{6}\left(\mathrm{NO}_{3}{ }^{-}, \mathrm{CF}_{3} \mathrm{SO}_{3}{ }^{-}, \mathrm{BF}_{4}{ }^{-}\right)$except for complex 11, where the use of a large dodecylsulfate anion $\left(\mathrm{H}_{25} \mathrm{C}_{12} \mathrm{OSO}_{3}{ }^{-}\right)$bearing a long alkyl chain is meant to induce possible modifications of the mesogenic properties (melting point and kind of mesophase, for example) as a consequence of structural distortions produced by the presence of a chain in the anion. Optical, thermal and thermodynamic data are collected in Table 2.

Table 2. Optical, thermal and thermodynamic data of silver compounds $8-12$

\begin{tabular}{|c|c|c|c|c|c|}
\hline Compound & Transition $^{a}$ & $\begin{array}{l}\mathbf{T}^{b} \\
{ }^{\circ} \mathrm{C}\end{array}$ & $\begin{array}{l}\mathbf{\Delta H} \\
\mathrm{kJmol}^{-1}\end{array}$ & $\begin{array}{l}\mathbf{\Delta S} \\
\mathrm{JK}^{-1} \mathrm{~mol}^{-1}\end{array}$ & \\
\hline \multirow[t]{2}{*}{8} & $\mathrm{C}-\mathrm{SmA}$ & 102.6 & 13.3 & 35.4 & \\
\hline & $\mathrm{SmA}-$ dec. & $160^{c}$ & - & - & \\
\hline \multirow[t]{2}{*}{9} & $\mathrm{C}-\mathrm{SmA}$ & 90.5 & 23.9 & 80.5 & \\
\hline & $\mathrm{SmA}-$ dec. & $200^{c}$ & - & - & \\
\hline \multirow[t]{4}{*}{10} & $\mathrm{C}-\mathrm{X}$ & 77.3 & 37.1 & 105.9 & \\
\hline & $\mathrm{X}-\mathrm{C}^{\prime}$ & 94.9 & -12.6 & -34.3 & \\
\hline & $C^{\prime}-\mathrm{SmA}$ & 137.5 & 29.3 & 71.4 & \\
\hline & $\mathrm{SmA}-\mathrm{I}$ & 167.6 & 9.6 & 21.8 & \\
\hline \multirow[t]{4}{*}{11} & $\mathrm{C}-\mathrm{C}^{\prime}$ & 63.7 & -4.4 & $-13,1$ & \\
\hline & $\mathrm{C}^{\prime}-\mathrm{C}^{\prime}$, & 100.8 & 16.8 & 44,9 & \\
\hline & $C^{\prime \prime}-\mathrm{SmA}$ & 123.5 & 12.8 & 32,3 & \\
\hline & $\mathrm{SmA}-\mathrm{I}$ & 138.1 & 3.2 & 7,8 & \\
\hline \multirow[t]{2}{*}{12} & $\mathrm{C}-\mathrm{SmA}$ & 144.1 & 25.3 & 60.6 & \\
\hline & $\mathrm{SmA}-$ dec. & $175^{c}$ & - & - & \\
\hline
\end{tabular}

All the mesomorphic silver complexes display only a smectic A mesophase (SmA). This is a very common mesophase in ionic liquid crystals, ${ }^{32}$ identified in polarized optical microscopy by 
its characteristics fan shaped focal conic texture (Figure 5). Some compounds show crystal-tocrystal transitions before melting. Although most of them undergo decomposition upon reaching the clearing point to the isotropic state, the SmA phase is stable in a large temperature range.

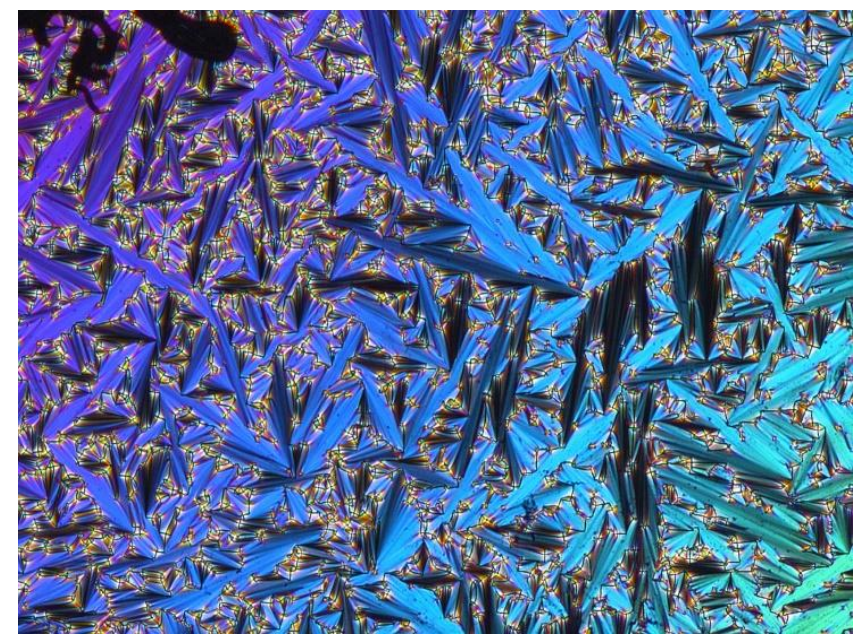

Figure 5. Polarized optical microscopic texture $(\times 100)$ observed for $\mathbf{1 0}$ (chosen as a representative example) upon cooling from the isotropic liquid at $154{ }^{\circ} \mathrm{C}$.

The order in the melting and clearing points of mesomorphic ionic complexes for the series $\left[\mathrm{Ag}(\mathrm{CNR})_{2}\right] \mathrm{X}(\mathbf{9 - 1 2})$ shows a dependence on the anion. All of them melt to a SmA phase, and two of them (9 and 12), decompose at clearing. The melting temperatures follow the trend $\mathrm{NO}_{3}{ }^{-}<\mathrm{C}_{12} \mathrm{H}_{25} \mathrm{OSO}_{3}{ }^{-}<\mathrm{CF}_{3} \mathrm{SO}_{3}{ }^{-}<\mathrm{BF}_{4}^{-}$. Interestingly, the clearing temperatures follow a different trend $\mathrm{C}_{12} \mathrm{H}_{25} \mathrm{OSO}_{3}{ }^{-}<\mathrm{CF}_{3} \mathrm{SO}_{3}{ }^{-}<\mathrm{BF}_{4}{ }^{-}<\mathrm{NO}_{3}{ }^{-}$, in which the lowest clearing temperature corresponds to $\mathrm{C}_{12} \mathrm{H}_{25} \mathrm{OSO}_{3}{ }^{-}$. This behavior can be rationalized with the support of the structural information of their analogous methyl derivatives 4-6.

In X-ray studies of ionic mesophases the positions of the anions are hard to localize, and it is also difficult to get crystals of the compounds having long alkyl or alkoxy chains for a single crystal study. It is usually believed that small anions will find some place close to the metal center of the complex cation so as to maximize stabilizing coulombic interactions. In this study, 
the single crystal results on 4-6 support this belief and allow us to consider that this structural arrangement is a reasonable starting point for the discussion. It should be considered from the beginning that complex 11 clearly differs from the others in spatial requirements and nature of its anion, and differences in behavior should be expected. Since segregation of hydrophilic and lipophilic molecular zones is a usual driving force for the anisotropic packing in liquid crystals, it is reasonable to imagine that $\mathrm{C}_{12} \mathrm{H}_{25} \mathrm{OSO}_{3}{ }^{-}$will have a strong tendency to situate the $\mathrm{SO}_{3}{ }^{-}$head close to the metal as it happens with $\mathrm{CF}_{3} \mathrm{SO}_{3}{ }^{-}$, and the long alkoxy chain in the same zone as the long chains of the cation. In related mesomorphic ionic silver amine complexes $\left[\mathrm{Ag}\left(\mathrm{NH}_{2}-\mathrm{n}\right.\right.$ $\left.\left.\mathrm{C}_{\mathrm{n}} \mathrm{H}_{2 \mathrm{n}+1}\right)_{2}\right] \mathrm{X}\left(\mathrm{X}=\mathrm{NO}_{3}^{-}, \mathrm{BF}_{4}^{-}\right),{ }^{33}$ it has been established that the melting point mainly involves the "melting of the chains" (that is, the increase of gauche/all trans ratio of carbon conformations, which decreases the length and increases the curling of the chain), whereas the clearing point (SmA-I transition) involves the disruption of the anion-cation interactions and the ordered arrangement. According to this, the stronger barrier to formation of an isotropic liquid (clearing temperature) is expected and found for the smaller anions, which are easier to accommodate close to the metal center and create the stronger coulombic interactions $\left(\mathrm{NO}_{3}{ }^{-}\right.$, $\mathrm{BF}_{4}^{-}$); amongst them, $\mathrm{NO}_{3}^{-}$, which additionally can make chemical bonding to the metal, displays the higher clearing temperature. The bulkier $\mathrm{CF}_{3} \mathrm{SO}_{3}{ }^{-}$shows a lower clearing temperature. Finally, the size of $\mathrm{C}_{12} \mathrm{H}_{25} \mathrm{OSO}_{3}{ }^{-}$increases in the region close to the metal center as its chain curls as a consequence of the melting of chains (the anion becomes less linear and more round), which contributes to weaken the coulombic interactions and facilitates the SmA to I clearing transition.

Regarding the type of molecular association in the mesophase, it is important to note that no significant changes are observed in the IR spectra of the materials in the solid state at room 
temperature and in the mesophase (Figure 6). This suggests that a supramolecular arrangement similar to the solid state is basically maintained upon melting. However, it is worth noting that the wavelengths of the $\mathrm{C}-\mathrm{H}$ stretching modes, which appear just below $3000 \mathrm{~cm}^{-1}$, slightly increase with temperature. The process is reversible, and the initial wavelength values are recovered upon cooling, suggesting an increasing gauche/all trans ratio of the configurations of the chains as the temperature increases, as expected. ${ }^{34}$

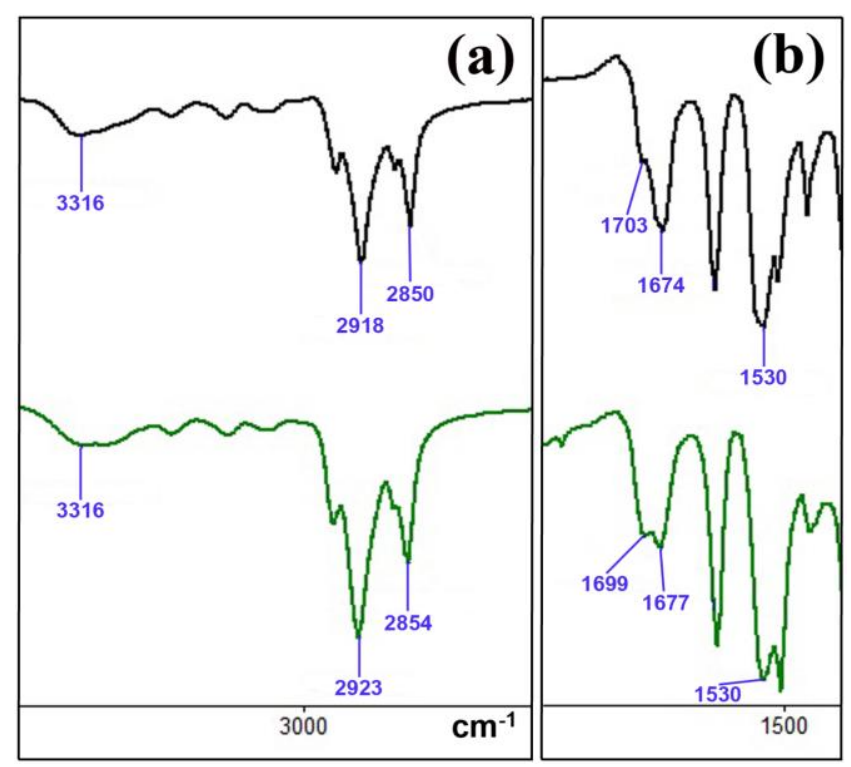

Figure 6. IR by ATR spectra of 9 in the solid at room temperature (upper curve) and in the SmA mesophase (lower curve). a) $\mathrm{N}-\mathrm{H}$ and $-\mathrm{CH}_{2}$ - stretching region. b) $\mathrm{C}=\mathrm{O}$ and $\mathrm{N}-\mathrm{C}=\mathrm{O}$ stretching region

Comparing the mesogenic behavior of 8-12 with that of their analogous silver complexes bearing a para-alkoxyphenylisocyanide (Ag-API), ${ }^{17}$ both cases display smectic mesophases. However, while Ag-API shows a SmC phase in addition to a SmA, our complexes show only a SmA with higher melting points due to the amide interactions. The same amide interactions 
stabilize better the mesophase, reaching clearing points $10-50{ }^{\circ} \mathrm{C}$ higher than the Ag-API complexes.

\section{CONCLUSIONS}

We have isolated unusual silver(I) complexes with the bifunctional 4-isocyanoacetanilide and 4-isocyano-decylanilide ligands. These complexes are promising models of building blocks to prepare rationally supramolecular systems. The isocyanide function coordinates to the metal center, and the amido function is able to establish hydrogen bonds and other weak interactions through the amide group. In fact, the silver 4-isocyanoacetanilide complexes 2-6 generate layered crystal superstructures through weak interactions $(\mathrm{Ag} \cdots \mathrm{O}, \mathrm{O} \cdots \mathrm{H}-\mathrm{N}, \mathrm{F} \cdots \mathrm{H}-\mathrm{N}$ and/or $\mathrm{O} \cdots \mathrm{H}-\mathrm{O}$ ) suitable to prepare mesomorphic materials. In effect, using a nonyl substituent (instead of methyl) in the 4-isocyanoacetanilide ligand gives rise to the mesomorphic 4-isocyanodecylanilide complexes 8-12, which display stable smectic mesophases in a wide range of temperatures. These results demonstrate the ability of the amide group to modulate the supramolecular structure and properties in these silver complexes with functional isocyanides.

\section{ASSOCIATED CONTENT}

\section{Supporting Information Available}

X-ray crystallographic information in CIF format for 2-6. Synthesis, CHN analysis and spectroscopic characterization for 1-12. Bond distances and angles, ORTEP plots and unit cells for 2-6. Experimental and calculated Powder X-Ray Diffraction diagrams for 2-6. Crystallographic information files for $\mathbf{2 - 6}$ are also available from the Cambridge Crystallographic Data Center via http://www.ccdc.cam.ac.uk/data_request/cif (CCDC deposition 
numbers 1011688-1011692). This information is available free of charge via the Internet at http://pubs.acs.org.

\section{AUTHOR INFORMATION}

\section{Corresponding author}

E-mail: espinet@qi.uva.es Tel.: +34 983186336

\section{ACKNOWLEDGEMENTS}

This work was sponsored by the Spanish Ministerio de Economía y Competitividad (Project CTQ2011-25137) and the Junta de Castilla y León (Project VA302U13). We are indebted to Dr.

J. M. Martín-Álvarez, for his valuable help in the resolution of the structures and to Dr. G. Alcaide for her assistance in the syntheses.

\section{REFERENCES}

(1) (a) Singleton, E.; Oosthuizen, H. E. Adv. Organomet. Chem. 1983, 22, 209-309. (b) Carnahan, E. M.; Protasiewicz, J. D.; Lippard, S. J. Acc. Chem. Res. 1993, 26, 90-97. (c) Weber, L.; Angew. Chem., Int. Ed. 1998, 37, 1515-1517. (d) Sharma, V.; Piwnica-Worms, D. Chem. Rev. 1999, 99, 2545-2560.

(2) (a) Michelin, R. A.; Guedes da Silva, M. F. C.; Pombeiro, A. J. L. Coord. Chem. Rev., 2001, 218, 75-112; (b) Basato, M.; Benetollo, F.; Facchin, G.; Michelin, R. A.; Mozzon, M.; Pugliese, S.; Sgarbossa, P.; Mazzega Sbovata, S.; Tassan, A. J. Organomet. Chem. 2004, 689, 454-462. (c) Bartolomé, C.; Garcia-Cuadrado, D.; Ramiro, Z.; Espinet, P. Inorg. Chem. 2010, 49, 9758-9764. (d) Edwards, P. G.; Hahn, F. E.; Dalton Trans. 2011,40, 10278-10288.

(3) (a) Wang, S.; Mayr, A.; Cheung, K.-K. J. Mater. Chem., 1998, 8, 1561-1565. (b) Mayr, A.; Guo, J. Inorg. Chem. 1999, 38, 921-928. (c) Lu, Z.-L.; Mayr, A.; Cheung, K.-K. Inorg. Chim. Acta 1999, 284, 205-214. (d) Bartolomé, C.; Carrasco-Rando, M.; Coco, S.; Cordovilla, C.; Espinet, P.; Martín-Alvarez, J. Organometallics 2006, 25, 2700-2703. (e) Coco, S.; Cordovilla, C.; Dominguez, C.; Espinet, P. Dalton Trans. 2008, 6894-6900. (f) Arias, J. Bardaji, M.; Espinet, P.; Folcia, C. L.; Ortega, J.; Etxebarria, J.; Inorg. Chem. 2009, 48, 6205-6210. (g) Cordovilla, C.; Coco, S.; Espinet, P.; Donnio, B. J. Am. Chem. Soc. 2010, 132, 1424-1431. 
(4) Chico, R.; Castillejos, E.; Serp, P.; Coco, S.; Espinet, P. Inorg. Chem. 2011, 50, 86548662 .

(5) Kim, M.; Euler, W. B.; Rosen. W.; J. Org. Chem., 1997, 62, 3766-3769.

(6) Sharma, C. V.; Rogers, R. D.; Crys. Eng., 1998, 1, 19-38.

(7) Bardají, M.; Miguel-Coello, A. B.; Espinet, P. Inorg. Chim. Acta, 2012, 386, 93-101.

(8) (a) Gerasimchuk, N. Polymers, 2011, 3, 1475-1511. (b) Young, A. G.; Hanton, L. R.; Coord. Chem. Rev., 2008, 252, 1346-1386. (c) Chen, C.-L.; Kang, B.-S.; Su. C.-Y. Aust. J. Chem. 2006, 59, 3-18. (d) Khlobystov, A. N.; Blake, A. J.; Champness, N. R.; Lemenovskii, D. A.; Majouga, A. G.; Zyk, N. V.; Schroder, M. Coord. Chem. Rev., 2001, 222, 155-192

(9) (a) Lehn. J. M. Polym. Int. 2002, 51, 825-839. (b) Lehn, J. M. In Supramolecular Polymers (Second Edition); Ciferri, A. Ed. CRC Press, Taylor \& Francis: Boca Raton, FL, 2005, pp 3-27. (c) Besenius, P.; Cormack, P. A. G. In Supramolecular Chemistry: From Molecules to Nanomaterials. Gale, P. A., Steed, J. W. Eds.; Wiley, 2012, vol 7, pp 3321-3336.

(10) (a) Fortin, D.; Drouin, M.; Turcotte, M.; Harvey, P. D. J. Am. Chem. Soc. 1997, 119, 531541. (b) Li, M.X.; Cheung, K.K.; Mayr. A. J. Solid State Chem. 2000, 152, 247-252. (c) Bartolomé, C.; Espinet, P.; Martín-Álvarez, J. M.; Soulantica, K.; Charmant. J. P. H. Inorg. Chim. Acta, 2010, 363, 1864-1868.

(11) Cai, Y.-P.; Zhang, H.-X.; Xu, A.-W.; Su, C.-Y.; Chen, C.-L.; Liu, H.-Q.; Zhang, L.; Kang, B.-S. J. Chem. Soc., Dalton Trans. 2001, 2429-2434.

(12) (a) Yuan, Z.; Dryden, N.H.; Li, X.; Vittal, J.J.; Puddephatt, R.J. J. Mater. Chem. 1995, 5, 303-307. (b) Effendy, G.; Lobbia, G.; Pettinari, C. ; Santini, C.; Skelton, B. W.; White, A. H. Inorg. Chim. Acta, 2000 298, 146-153. (c) Dias, H. V. R.; Singh, S. Inorg. Chem. 2004, 43, 7396-7402. (d) Djordjevic, B.; Schuster, O.; Schmidbaur, H. Z. Naturforsch 2006, 61b, 6-10. (e) Weidner, T.; Ballav, N.; Zharnikov, M.; Priebe, A.; Long, N. J.; Maurer, J.; Winter, R.; Rothenberger, A.; Fenske, D.; Rother, D.; Bruhn, C.; Fink, H.; Siemeling. U. Chem. Eur. J. 2008, 14, 4346-4360 (f) Arias, J.; Bardají, M.; Espinet, P. Inorg. Chim. Acta, 2011, 365, 501504

(13) Weidner, T.; Ballav, N.; Zharnikov, M.; Priebe, A.; Long, N. J.; Maurer, J.; Winter, R.; Rothenberger, A.; Fenske, D.; Rother, D.; Bruhn, C.; Fink, H.; Siemeling. U. Chem. Eur. J. 2008, 14, 4346-4360.

(14) Biradha, K.; Desiraju, G.; Braga, D.; Grepioni. F. Organometallics 1996, 15, 1284-1295.

(15) (a) Pucci, D. Liq. Cryst., 2011, 38, 1451- 1465. (b) Bruce, D. W. Acc. Chem. Res., 2000, $33,831-840$

(16) (a) Espinet, P.; Esteruelas, M. A.; Oro, L.; Serrano, J. L.; Sola, E. Coord. Chem. Rev. 1992, 117, 215-274; (b) Metallomesogens. Serrano, J. L. Ed. VCH: Weinheim, 1996; (c) Donnio, B.; Guillon, D.; Bruce, D. W.; Deschenaux, R. Metallomesogens, in Comprehensive Organometallic Chemistry III: From Fundamentals to Applications; Crabtree, R. H., Mingos D. M. P. Eds. Elsevier: Oxford, UK, 2006, vol. 12, chapter 12.05, pp. 195-294; (d) Bruce, D. W. in Inorganic Materials. Bruce, D. W., O'Hare, D. Eds., Wiley: Chichester, 2nd edition, 1996, chapter 8 .

(17) Benouazzane, M.; Coco, S.; Espinet, P.; Martin-Alvarez, J. M.; Barberá, J. J. Mater. Chem. 2002, 12, 691-696.

(18) CrysAlisPro Software system, version 1.171.33.51, 2009, Oxford Diffraction Ltd, Oxford, UK. 
(19) Baena, M. J.; Espinet, P.; Folcia, C. L.; Ortega, J.; Etxebarria, J. Inorg. Chem. 2010, 49, $8904-8913$.

(20) SHELXTL program system, version 5.1; Bruker Analytical X-ray Instruments Inc.; Madison, WI, 1998.

(21) SHELXTL Program System Version 5.1; Bruker Analytical X-ray Instruments Inc., Madison, WI, 1998.

(22) Flack, H. D. Acta Cryst. 1983, A39, 876-881

(23) Johnson, S. W.; Eckert, J.; Barthes, M.; McMullan, R. K.; Muller. M.; J. Phys. Chem. 1995, 99, 16253-16260.

(24) Kajitani, T.; Kohmoto, S.; Yamamoto, M.; Kishikawa, K. Chem. Mater. 2004, 16, 229231.

(25) Steiner. T. Angew. Chem. Int. Ed. 2002, 41, 48-76

(26) (a) See, for example, Guitard, A.; Mari, A.; Beauchamp, A. L.; Dartiguenave, Y.; Dartiguenave, M. Inorg. Chem. 1983, 22,1603-1606. (b) Djordjevic, B.; Schuster, O.; Schmidbaur, H. Z. Naturforsch, B: Chemical Sciences, 2006, 61, 6-10.

(27) (a) Taylor, R.; Kennard, O. Acc. Chem. Res. 1984, 17, 320-326. (b) Steiner, T.; Saenger, W.; Acta Cryst. 1993, A49, 379-384. N-H = $1.03 \AA, \mathrm{O}-\mathrm{H}=0.97 \AA, \mathrm{C}-\mathrm{H}=1.07 \AA$.

(28) (a) Stein, R. A.; Knobler, C. Inorg. Chem. 1977, 16, 242-245; (b) Meiners, J. H.; Clardy, J. C.; Verkade, J. G. Inorg. Chem. 1975, 14, 632-636.

(29) $r_{\text {cov }}(\mathrm{Ag})+r_{\text {cov }}(\mathrm{O})=2.14 \AA ; r_{\text {ion }}\left(\mathrm{Ag}^{+}\right)+r_{\text {ion }}\left(\mathrm{O}^{2-}\right)=2.55 \AA$. Cotton, F. A.; Wilkinson, G.; Gauss, P. L. Basic Inorganic Chemistry, 3rd ed.; Wiley: New York, 1995; p 61.

(30) Ullrich, S.; Müller-Dethlefs. K. J. Phys. Chem. A. 2002, 9181-9187.

(31) Zhang, Q-L.; Hu, P.; Zhao, Y.; Feng, G-W.; Zhang, Y-Q.; Zhu, B-X.; Tao, Z. J. Solid State Chem., 2014, 210, 178-187

(32) Binnemans, K. Chem. Rev. 2005, 105, 4148 -4204

(33) Albéniz, A. C.; Barberá, J.; Espinet, P.; Lequerica, M. C.; Levelut, A. M.; López-Marcos, F. J.; Serrano, J. L. Eur. J. Inorg. Chem. 2000, 133-138.

(34) Snyder, R. J.; Strauss, H. L.; Elliger, C. A. J. Phys. Chem. 1982, 86, 5145-5150. 


\section{For Table of Contents use only}

\section{SYNOPSIS}

The first examples of metal complexes derived from an amido-functionalized isocyanide $(\mathrm{CNR}=$ $\left.\mathrm{CN}-\mathrm{C}_{6} \mathrm{H}_{4}-\mathrm{NHCOR}, \mathrm{R}=\mathrm{Me}, \mathrm{C}_{9} \mathrm{H}_{19}\right)$ are reported. The methyl derivatives show a layered crystalline structure based on the assembling of polymeric chains formed by $\mathrm{Ag}-\mathrm{O}=\mathrm{C}_{\mathrm{amide}}$ interactions, which is retained in the smectic mesophase produced with $\mathrm{R}=\mathrm{C}_{9} \mathrm{H}_{19}$.

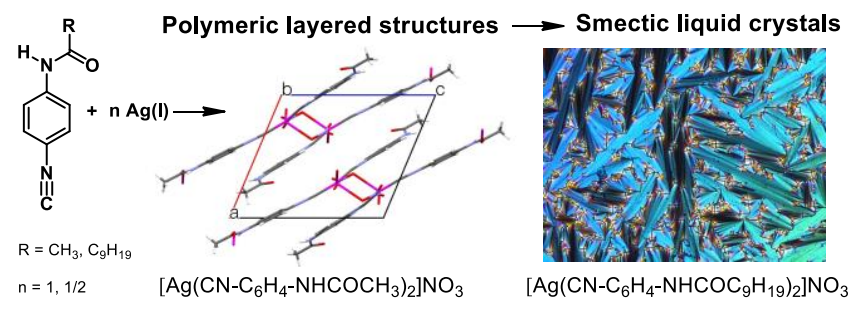

